\title{
GAMBARAN KOPING WANITA DENGAN INFERTILITAS DI KELURAHAN PUDAK PAYUNG KOTA SEMARANG
}

\author{
Priharyanti Wulandari ${ }^{1)}$, Arifianto ${ }^{2)}$, Ulfa Nur Faizah ${ }^{3)}$ \\ Program Studi Ners STIKES Widya Husada Semarang \\ Jl. Subali Raya no. 12 krapyak semarang, telp 024-7612988-7612944 \\ Email :wulancerank@yahoo.co.id
}

\begin{abstract}
ABSTRAK
Latar Belakang : kasus infertilitas diperkirakan terus naik tiap tahunnya. Wanita dengan infertilitas akan merasakan hal yang berbeda dengan wanita yang telah memiliki anak. Kondisi diri sendiri, lingkungan, suami, keluarga dari pihaknya dan pihak suami sangat mempengaruhi koping yang dilakukan. Tujuan penelitian ini adalah untuk mengetahui gambaran koping wanita dengan infertilitas di kelurahan pudak payung kota semarang. Metode : penelitian ini merupakan penelitian kualitatif dengan pendekatan fenomenologi. Menggunakan teknik purposive sampling dengan melibatkan 4 partisipan. Hasil : penelitian ini menunjukkan lima tema utama yaitu : (1) dampak infertilitas terhadap perasaan, (2) sikap suami, (3) upaya pengobatan dan sumber informasi, (4) koping, (5) sikap keluarganya dan keluarga suami. Kesimpulan : wanita dengan infertilitas di kelurahan pudak payung kota semarang menggunakan bentuk problem focused coping.
\end{abstract}

Kata Kunci : wanita, infertilitas, koping.

\section{PENDAHULUAN}

Berdasarkan laporan WHO pada tahun 2009 secara global diperkirakan bahwa adanya kasus infertilitas pada $8-10 \%$ pasangan, yaitu sekitar 50 hingga 80 juta pasangan di dunia. Di Indonesia pada tahun 2007, WHO memperkirakan dari sekitar 30 juta pasangan usia subur terdapat 3-4,5 juta atau sekitar $10-15 \%$ pasangan yang memiliki masalah kesuburan, bahkan menurut Rikesdas pada tahun 2013 jumlahnya meningkat menjadi 50 juta pasangan atau $15-20 \%$ dari seluruh pasangan usia subur (Trisnawati, 2015).

Berdasarkan data statistik BKKBN di Jawa Tengah pada tahun 2010 jumlah Pasangan Usia Subur (PUS) sebanyak 6 juta dan mengalami masalah infertil sebesar $5,5 \%$. Sedangkan di Kota Semarang sendiri, menurut Badan Pusat Statistik (BPS) laju pertumbuhuan pada tahun 2008 sampai 2013 terus menurun dari 1.86\% berangsur hingga $0.83 \%$, mengalami kenaikan pada tahun 2014 namun kembali menurun di tahun 2015. Pada Tahun 2014 sebanyak $0.97 \%$ dan pada tahun 2015 menjadi $0.59 \%$. Di Kelurahan Pudak Payung, Pasangan Usia Subur (PUS) pada tahun 2013 sampai 2014 mengalami kenaikan dari $1.9 \%(5,180)$ menjadi $2.01 \%$ $(5,352)$ sedangkan angka pengguna $\mathrm{KB}$ pada tahun yang sama mengalami penurunan yaitu dari $2.03 \% \quad(4,702)$ menjadi $1.64 \%$ (3.939), hal ini juga berbanding lurus dengan menurunnya angka kelahiran, yang bermula 1.2\% (318) menjadi $1.1 \%$ (310).

Menurut hasil penelitian Ramamurthi et.al (2016) mengenai Psychological Impact And Coping Strategies Among Women With Infertility In India, menyatakan bahwa dari 150 wanita hanya 
$50 \%$ dari mereka yang akan melakukan konseling. Sebanyak 58\% didapatkan wanita dengan tingkat kecemasan tinggi dan menarik diri sebesar 32\%. Mekanisme koping yang umum dilakukan oleh wanita dengan infertil yaitu menghabiskan waktu dengan hobi $13 \%$, menangis sebanyak $11 \%$ dan berkumpul bersama teman $10 \%$, lebih berfokus pada pekerjaan sebanyak $6 \%$.

International Conference Population and Development (ICPD) pada tahun 1994 menyatakan bahwa kesehatan reproduksi adalah sebagai hasil akhir keadaan sehat sejahtera secara fisik, mental, dan sosial dan tidak hanya bebas dari penyakit atau kecacatan dalam segala hal yang terkait dengan sistem, fungsi serta proses reproduksi. Sedangkan ruang lingkup pelayanan reproduksi di Indonesia mencangkup salah satunya ialah pencegahan dan penanganan infertilitas, namun yang perlu diketahui, dalam Peraturan Pemerintah Republik Indonesia Nomor 19 Tahun 2016 mengenai Jaminan Kesehatan pasal 25 menyatakan bahwa pelayanan untuk mengatasi infertilitas tidak dijamin oleh pemerintah.

\section{METODE PENELITIAN}

Penelitian ini menggunakan metode penelitian kualitatif dengan pendekatan fenomenologi. Moloeng (2011) mendefinisikan jenis penelitian kualitatif adalah penelitian yang bermaksud untuk memahami fenomena tentang apa yang dialami oleh subjek penelitian. Tujuan penelitian fenomenologi adalah menjelaskan pengalaman apa yang dialami oleh individu dalam kehidupan ini, termasuk berinteraksi dengan orang lain (Sulistyaningsih, 2011).

Partisipan dalam penelitian ini sebanyak 4 partisipan. Sampel pada penelitian kualitatif bukan dinamakan responden, tetap sebagai narasumber, atau partisipan, informan dalam penelitian (Sugiyono, 2014). Pengambilan partisipan yang digunakan adalah non probability sampling dengan teknik purposive sampling.
Peneliti menggunakan teknik wawancara mendalam jenis wawancara semistuktur untuk mendapatkan data dari partisipan. Hasil wawancara ditulis dalam bentuk transkrip kemudian mencari kata kunci sesuai dengan tujuan. Dari kata kunci yang telah terkumpul dibentuk suatu kategori lalu membentuk suatu tema. Dari tiap-tiap tema dideskripsikan dalam bentuk narasi dan didukung oleh pernyataan dari tiap-tiap partisipan. Setelah dilakukan transkrip data lalu kembali ke partisipan untuk melakukan member check dan bertanya kepada partisipan bila ada data yang kurang sebagai uji validitas penelitian.

\section{HASIL PENELITIAN}

Partisipan penelitian berjumlah 4 orang. Partisipan 1 yaitu Ny. R, partisipan 2 yaitu Ny. T, partisipan 3 yaitu Ny. B, partisipan 4 yaitu Ny. I. seluruh partisipan berusia lebih dari 35 tahun dengan usia pernikahan lebih dari 1 tahun.

\section{A. Identifikasi dampak infertilitas terhadap perasaan wanita dengan infertilitas di Kelurahan Pudak Payung Kota Semarang.}

Berdasarkan hasil wawancara terhadap wanita dengan infertilitas diperoleh beberapa pernyataan mengenai perasaan mereka ketika menyadari bahwa setelah 1 tahun pernikahan belum mendapat keturunan, yaitu berharap, sedih, khawatir, takut dan kesepian.

Disaat usia saya masih belum mencapai 40 keinginan itu memang masih ada" (P1)

"waktu itu sangat sangat sangat berharap. Mana ada sih mbak orang menikah belum

dikaruniai anak tidak berharap, pasti berharap sangat sangat berharap." (P2)

"saya itu kepinginnya ya ndang punya momongan." (P3)

"Kalo liat bayi ya kepingin" (P4) 
B. Identifikasi sikap suami terhadap istri dengan infertilitas di Kelurahan Pudak Payung Kota Semarang

Sikap suami yang ditunjukkan dalam penelitian ini diantaranya adalah mengantar/menemani ketika pengobatan, setia dengan pasangan, dan menerima kondisi istri.

"suami tidak menuntut. Karena dalam agama kami menikah itu bukan hanya semata untuk mendapatkan anak tetapi menyatukan dua orang dalam satu cinta. Saling menerima kelebihan dan kekurangan, bukan hanya kelebihan saja." (P1)

"Memang dari awal dia sudah bilang kalo nanti hasil akhirnya tetep tidak berhasil kita yo apa cari momongan lewat jalan lain yo nggak apa-apa." (P2)

"bapake kan orangnya santai ndak pernah menuntut sama sekali, Ndak pernah nuntut kamu harus punya anak kamu harus punya keturunan.." (P3)

"Sampai saat ini suami tidak menuntut untuk masalah itu mbak." (P4)

C. Identifikasi Upaya Pengobatan Dan Sumber Informasi Pengobatan Pada Wanita Dengan Infertilitas Di Kelurahan Pudak Payung Kota Semarang

Pengobatan yang dilakukan mencangkup pengobatan medis dan non-medis. Pengobatan medis meliputi pemeriksaan ke dokter dan konsumsi obat, sedangkan pengobatan non-medis berupa pijat dan minum jamu. Sedangkan untuk sumber informasi pengobatan didapat diantaranya dari tetangga, saudara dan teman. “...dari tetanga, teman." (P1)

"Kalo prana awalnya dari temen suami. Dulu kan hp nggak secanggih sekarang, infonya ya lewat temen, sodara, tetangga-tetangga." (P2)

"Infonya dari tetangga, juga dari temen." (P3)

"Dari saudara, dari tetangga" (P4)

D. Koping Wanita Dengan Infertilitas di Kelurahan Pudak Payung Kota Semarang.

Penelitian ini menunjukkan upaya yang dilakukan oleh wanita dengan infertilitas diantaranya adalah menyibukkan diri, bercerita tentang masalahnya, berdoa, tidak putus asa dalam pengobatan, adopsi dan pasrah.

"karna pasti dibalik semua itu ada hal yang baik. Tuhan yang memberi pada saya maka Tuhan sendiri yang akan menyelesaikan." (P1)

"..lama-lama saya lupa, dengan kesibukan merawat si kecil itu saya lupa akan keinginan saya sendiri, yasudah. Fisik saya yo sudah lemah ok saya sudah sadar nek wis tuo-lah" (P2)

"Iya pasrah, Iha kalo ndak pasrah gimana? Kalo saya pikir nemen-nemen malah saya yang sakit, memang tuhan berkehendak gitu ok." (P3)

"saya pasrahkan semuanya mbak." (P4)

E. Identifikasi sikap keluarga pasangan dan istri dengan infertilitas di Kelurahan Pudak Payung Kota Semarang

Penelitian menunjukkan bahwa keseluruhan keluarga wanita dengan infertilitas dan juga keluarga suami 
mendukung/memotivasi dan tidak menunjukkan sikap menuntut atas kondisinya.

"keluarga pasti, 'yang kuat..', 'yang tabah..' 'sabar..', 'kita persembahkan unuk Tuhan, berikan saja pada Dia." (P1)

"Keluarga tidak menuntut" (P1)

"Keluarga saya dan keluarga suami tidak pernah mempermasalahkan kondisi saya, dan saya adopsipun mereka mendukung. Justru yang awal-awal yang mendorong saya adopsi itu malah kakak sepupu saya, dan Alhamdulillah setelah saya ambil, semua dari pihak suami dan keluarga saya tidak mempermasalahkan kondisi saya, keberadaan anak saya." (P2)

"Keluarga ndak ada yang
nuntut.." (P3)

"lya mendukung, nggak ada yang "bojomu kui ora nduwe anak..." (P3)

"keluarga mendukung semua mbak."(P4)

\section{PEMBAHASAN}

\section{A. Identifikasi dampak infertilitas terhadap perasaan wanita dengan infertilitas di Kelurahan Pudak Payung Kota Semarang.}

Berdasarkan hasil penelitian didapatkan bahwa Seluruh partisipan menyatakan bahwa dengan usia pernikahan mereka yang lebih dari satu tahun, mereka sangat ingin dan berharap memiliki anak. Tujuan pernikahan salah satunya adalah untuk memiliki keturunan, apabila pasangan dihadapkan pada kondisi belum hadirnya anak maka perasaan ingin dan berharap muncul. Hal tersebut sesuai dengan penelitian dari Soimah \& Hidayat (2011) mengenai Psikologi perempuan dengan masalah infertilitas di Yogyakarta, pasangan infertilitas berharap memiliki anak dan berharap untuk berhasil dalam proses pengobatan.

Adanya tetanga maupun kerabat yang sudah terlebih dahulu memiliki anak, hal itu membuat keinginan dan harapan memiliki anak semakin kuat. Apabila keinginan yang kuat tidak tercapai maka akan menimbulkan beberapa respon emosi negatif. Hal ini sesuai dengan yang dikemukakan oleh Aditya (2015) bahwa ada beberapa hal yang menjadi pemicu munculnya emosi negatif yaitu adanya perasaan tertekan, frustasi serta keinginan yang tidak tercapai.

Kesedihan juga dirasakan pada seluruh partisipan karena keinginan memiliki anak tidak terwujud, diantaranya menyatakan bahwa dirinya merasa sedih karena tidak bisa merasakan apa yang wanita hamil rasakan dan merasa berbeda dengan wanita lainnya. Sesuai dengan hasil penelitian dari Ulfah \& Mulyana (2014) terhadap 3 partisipan mengenai gambaran subjective well being pada wanita involuntary childless yang menyatakan bahwa kesedihan dirasakan oleh ketiga subjek ketika mereka ingin memiliki anak namun tidak mampu mendapatkannya. Sejalan dengan teori dari Sugiarti (2008) yang menyatakan bahwa wanita merasakan dampak negatif dari ketidakhadiran anak dalam pernikahan yang meliputi perasaan sedih yang mendalam, merasa menjadi wanita yang tidak sempurna, perasaan rendah diri dan kesepian.

Kesepian juga dirasakan oleh partisipan. Diantaranya mengatakan bahwa mereka kesepian karena tidak memiliki anak, ketika berada dirumah sendiri dan tidak memiliki kesibukan atau aktifitas. Wanita dengan infertilitas ketika tengah sendiri lebih cenderung hanya memikirkan masalah yang dialami dari pada mencari solusi untuk masalahnya, yang pada akhirnya semakin menambah perasaan negatif. Sesuai dengan teori dari Papalia (2009) masalah yang terjadi pada pasangan 
yang tidak memiliki anak akan mengalami kesepian.

Perasaan khawatir dan was-was juga dirasakan oleh seluruh partisipan karena belumnya memiliki anak. Diantaranya menyatakan perasaan khawatir muncul ketika memikirkan masa tuanya. Tidak bisa dipungkiri bahwa apabila seseorang menjadi tua mereka akan kesulitan untuk merawat diri sendiri, harapan salah satunya adalah keturunannya. Pasangan suami istri yang memiliki anak tentunya akan menaruh harapan besar terhadap anak-anaknya kelak. Hal ini sangat berbeda dengan pasangan yang memiliki anak khususnya pihak wanita, wanita mungkin akan lebih banyak berkhayal tentang bagaimana masa tuanya dan siapa yang selanjutnya akan meneruskan keluarga mereka. Sejalan dengan hasil penelitian dari Nurfita (2007) terhadap 3 pasangan suami istri, dalam penelitiannya mengemukakan bahwa cemas dan khawatir yang dirasakan oleh partisipan adalah kekhawatiran terhadap timbulnya masalah-masalah yang diakibatkan oleh kondisi infertilitas. Ahmadi (2009) menjelaskan bahwa suami istri yang mengalami ketidakhadiran anak membuat pewarisan kebudayaan pada keturunannya menjadi terhambat karena tidak hadirnya anak dalam keluarga.

Wanita yang belum memiliki anak akan menjadi lebih sensitif daripada wanita yang sudah memiliki anak, salah satunya mengenai pasangan. Ketidaksempurnaan yang dimiliki membuat wanita merasa takut apabila kehilangan pasangannya, berpaling terhadap wanita lain. Partisipan menyatakan bahwa mereka merasa takut apabila pasangan berpaling pada wanita lain, adapula yang menyatakan untuk menjawab perasaan takutnya dengan bertanya langsung pada pasangan. Sesuai dengan pendapat Aditya (2015) bahwa ketakutan bisa datang karena khawatir disakiti dan kehilangan seseorang.

\section{B. Identifikasi sikap suami terhadap istri dengan infertilitas di Kelurahan Pudak Payung Kota Semarang}

Suami memiliki peranan penting dalam mengurangi emosi negatif wanita akibat dari kondisinya, meskipun tidak bisa dipungkiri bahwa infertilitas merupakan stressor yang mempengaruhi kedua belah pihak pasangan, baik suami maupun istri. Menurut Sugiarti (2008) pasangan yang tidak bisa memiliki anak seringkali bergantung satu sama lain dalam hal dukungan sosial karena mereka tidak membicarakan masalah infertilitas dengan orang lain. Dukungan suami terhadap wanita dengan infertilitas meliputi beberapa sikap, diantaranya adalah menemani ketika ingin berobat. Adanya suami yang menemani pada saat pengobatan tentu membuat wanita merasa lebih tenang dan nyaman. Wanita akan lebih termotivasi karena dukungan dari suami yaitu selalu ada bersamanya. Menurut penelitian dari Marifah (2010) selain dukungan keluarga wanita lebih banyak mendapat ketenangan dari suami.

Setiap pasangan pasti menginginkan pernikahan yang harmonis, pernikahan yang penuh dengan ketenangan dan kebahagiaan. Keluarga harmonis dapat dicapai dengan adanya rasa saling mencintai, kesetian dan dukungan satu sama lain. Penelitian ini menunjukkan bahwa tidak adanya kasus perceraian. Menurut teori yang disampaikan oleh Vitahealth, (2007) dukungan diperlukan untuk saling berbagi perasaan dengan pasangan. Donkor \& Sandall (2009) dalam penelitiannya menunjukkan adanya dukungan suami seperti tidak mempermasalahkan kondisi istri dan masih setia.

Adaptasi merupakan proses penyesuaian diri terhadap tekanan dan tuntutan dengan lingkungan hidup. Pasangan yang tidak dikaruniai keturunan memiliki kehilangan harapan. Pada proses kehilangan, respon akhir adalah menerima atau pasrah. Seperti halnya sikap yang ditunjukkan oleh suami partisipan. Suami lebih banyak untuk tidak menuntut, sabar dan bahkan adapula yang menyarankan untuk adopsi. Suami yang menyarankan 
untuk adopsi ditujukan untuk kebahagiaan istri yang sangat ingin untuk memiliki anak, suami mungkin merasa kasihan dan tidak tega pada istri yang melakukan beberapa macam pengobatan dan terlihat sangat kelelahan serta kesakitan dengan pemeriksaan yang dilakukan. Hasil penelitian ini juga sesuai dengan penelitian yang dilakukan oleh Nurfita (2007) yang melakukan penelitian infertilitas terhadap pasangan infertilitas di Banda Aceh, pasangan menunjukkan sikap pasrah.

\section{Identifikasi Upaya Pengobatan Dan Sumber Informasi Pengobatan Pada Wanita Dengan Infertilitas Di Kelurahan Pudak Payung Kota Semarang}

Pada umumnya pasangan dengan infertilitas akan saling berdiskusi untuk menentukan pengobatan yang tepat agar segera memiliki keturunan, entah dalam medis maupun non-medis. Menurut Djuwantono (2008), saling menerima keadaan dan berdiskusi untuk mencari langkah yang tepat mengatasi keadaan infertilitas merupakan langkah awal yang harus pasangan lakukan. Menurut hasil penelitian ini, mayoritas partisipan mengaku pernah memeriksakan diri ke dokter dan meminum obat penyubur kandungan. Pengobatan non-medis juga lebih banyak dilakukan, bahkan beberapa partisipan mengaku lebih dahulu mencoba pengobatan tradisional seperti minum jamu maupun pijat. Hasil penelitian menunjukkan bahwa seluruh partisipan telah melakukan pijat dan meminum jamu. Hal tersebut sejalan dengan hasil penelitian dari Sitepu (2014) bahwa sebagian masyarakat suku Karo masih mencari pengobatan ke pijat tradisional dan mengkonsumsi ramuan tradisional.

Dalam mendapatkan informasi pengobatan, tak jarang pasangan akan saling mencari informasi atau mendapatkan informasi dari orang terdekat. Hasil penelitian ini menunjukkan bahwa beberapa sumber informasi pengobatan yang didapatkan oleh partisipan berasal dari teman, saudara dan tetangga. Sesuai dengan penelitian dari Nurfita (2007), untuk mengatasi kondisi infertilitas pasangan mencoba mencari informasi tentang pengobatan dan usaha-usaha lansung dari orang lain.

\section{Koping Wanita Dengan Infertilitas di Kelurahan Pudak Payung Kota Semarang.}

Penelitian ini menunjukkan bahwa wanita dengan infertilitas akan lebih menyibukkan diri untuk mengatasi rasa kesepian dan menghilangkan pikiranpikiran negatif. Pikiran-pikiran negatif biasanya muncul pada saat seseorang berada dalam kesendirian. Dalam menghadapi kesepian dan pikiran negative, perlunya kegiatan yang bisa mengalihkan pemikiran-pemikiran tersebut. Menurut Aditya (2015) mencari kesibukan adalah melakukan aktivitas hiburan bertujuan untuk mengalihkan pikiran dan perasaan pada suasana yang menyenangkan dan untuk melupakan kejadian atau sesuatu yang membuat emosi, individu membutuhkan sesuatu yang dapat mengalihkan emosi. Hasil penelitian Pedro (2015) mengenai koping wanita dengan infertilitas di Afrika Selatan menunjukkan bahwa wanita menyibukkan diri dengan pekerjaan dan hobi agar tidak terlalu memikirkan kondisi yang dialami. Pengalihan emosi inilah yang merupakan koping escape avoidance atau pelarian.

Penelitian menunjukkan bahwa partisipan dalam menyelesaikan masalahnya bercerita dengan saudara dan mendiskusikan dengan suami. Hasil penelitian di Ghana selatan (Donkor \& Sandall, 2009) juga menunjukkan bahwa wanita dengan infertilitas akan bercerita kepada orang lain mengenai kondisinya dan apa yang mereka rasakan untuk mendapatkan solusi. Koping jenis ini ialah seeking emotional support yaitu mencoba memperoleh dukungan emosional maupun sosial dari orang lain (Folkman \& lazarus dalam Ulina, 2016). Penelitian menunjukkan bahwa partisipan dalam 
menghadapi kondisinya dengan berdoa dan tahajud. Mungkin menurut beberapa individu, dengan berdoa hal yang tidak mungkin menjadi mungkin. Didukung dengan hasil penelitian dari Soimah \& Hidayat (2011) mengenai psikologi perempuan dengan masalah infertilitas di Magelang menunjukkan bahwa adanya peningkatan spiritual, seperti berdoa kepada Tuhan dan shalat tahajud. Menurut Afi (2006) berdoa merupakan mekanisme koping self control.

Beberapa partisipan menyatakan bahwa mereka tidak berputus asa dalam pengobatan. Individu yang tidak mudah berputus asa merupakan individu yang optimis. Sikap yang optimis adalah suatu sikap individu yang tidak kehilangan harapan. Teori tersebut diperkuat dengan hasil penelitian dari Pedro (2015) ditemukan bahwa wanita dengan infertilitas di Afrika Selatan yang melakukan pengobatan tidak berputus asa atas pengobatan yang dijalankan, mereka tetap beroptimis untuk dapat memiliki anak. Penelitian menunjukkan bahwa adanya pikiran untuk adopsi pada seluruh partisipan, namun salah satu diantaraya mengurunkan niatnya untuk adopsi dikarenakan tidak adanya persetujuan dari suami. Penelitian ini menunjukkan bahwa tiga partisipan telah mengadopsi anak, sedangkan salah satunya mengurungkan niatnya untuk mengadopsi. Berusaha mencari solusi untuk menghadapi kondisi merupakan bagian dari planful problem solving (Folkman \& Lazarus dalam ulina 2016).

Koping terakhir yang dilakukan oleh wanita dengan infertilitas adalah pasrah, menerima dengan ikhlas kondisinya. Penerimaan terhadap diri sendiri menunjukkan kepuasan dan kebahagiaan individu mengenai apa yang terjadi pada dirinya. Afi (2006) dalam penelitiannya tentang ibu yang belum memiliki keturunan menyatakan bahwa ibu akan mencoba mengendalikan perasaan dalam dirinya dengan memasrahkan keadaan dirinya.
Pasrah dan doa merupakan mekanisme koping self control.

\section{E. Identifikasi sikap keluarga pasangan dan istri dengan infertilitas di Kelurahan Pudak Payung Kota Semarang}

Penelitian menunjukkan bahwa dengan kondisinya, keluarga menunjukkan sikap yang positif. Keluarga yang dimaksud disini adalah keluarga dari pihak istri maupun pihak suami. Keduabelah pihak keluarga dalam penelitian ini menujukkan sikap mendukung dan tidak menunutut. Hal tersebut tentu saja akan memotivasi wanita dengan infertilitas dalam menghadapi kondisinya. Sesuai dengan hasil penelitian dari Mousavi dkk (2015) mengenai dukungan sosial dengan kesehatan mental wanita dengan infertilitas di Iran, menyebutkan bahwa adanya hubungan antara dukungan sosial dengan kesehatan mental, dukungan sosial dapat mengurangi emosi negatif dari wanita dengan infertilitas seperti merasa tidak berharga, marah, sedih dan cemas.

\section{KESIMPULAN DAN SARAN}

\section{A. Kesimpulan}

Berdasarkan hasil penelitian didapatkan Gambaran Koping Wanita Dengan Infertilitas di Kelurahan Pudak Payung Kota Semarang sebagai berikut:

1. Dampak infertilitas terhadap perasaan wanita dengan infertilitas meliputi dua hal yaitu perasaan terhadap diri sendiri dan orang lain. Pada wanita infertilitas, perasaan terhadap diri sendiri terkait dengan kondisinya adalah seperti berharap atau ingin memiliki anak, sedih atas kondisinya yang belum bisa memberikan anak, khawatir mengenai masa tuanya, takut apabila pasangan berpaling kepada wanita lain, dan kesepian. Adapun perasaan terhadap orang lain yaitu malu akan kondisi yang berbeda dengan wanita lain dan menjadikan kondisinya tersebut sebagai suatu beban. 
2. Identifikasi sikap suami terhadap wanita dengan infertilitas antara lain mengantar dan menemani pada saat melakukan pengobatan, namun ada pula suami yang menolak untuk diajak periksa. Ada pula suami yang menjadi lebih setia kepada istri, disisi lain terdapat suami yang ingin mendapatkan keturunan dengan jalan menikah dengan wanita lain. Sikap suami yang ditunjukkan pada akhirnya adalah menerima kondisi istri.

3. Pada identifikasi upaya pengobatan dan sumber informasi, pengobatan yang sudah dilakukan diantaranya adalah periksa dan melakukan pengobatan ke dokter dan mengkonsumsi obat penyubur. Dalam segi non-medis wanita dengan infertilitas memilih untuk minum jamu dan melakukan pijat. Sumber informasi banyak berasal dari teman, tetangga dan saudara.

4. Koping wanita dengan infertilitas yang ditunjukkan adalah menyibukkan diri dengan tujuan untuk menghilangkan pikiran-pikiran negatif, bercerita kepada keluarga ataupun kepada suami, berdoa dan peningkatan spiritual seperti tahajud, tidak berputus asa dalam pengobatan, pasrah akan kondisi yang dialaminya dan rencana adopsi.

5. Identifikasi sikap keluarga terhadap wanita dengan infertilitas meliputi dukungan sosial maupun moral dan tidak adanya suatu tuntutan yang memberatkan.

\section{B. Saran}

1. Bagi Wanita Dengan Infertilitas

Pada saat menghadapi kondisi dan masalah infertilitas diharapkan dapat melakukan koping atau sikap yang positif seperti menyibukkan diri dengan hal-hal yang bermanfaat, aktif dalam organisasi lingkungan, peningkatan spiritualitas, tidak putus asa dalam pengobatan dan ikhlas menerima kondisinya.
2. Bagi Perawat

Peran perawat sebagai edukator dan konselor dalam kasus ini cukup penting, dengan adanya edukasi masyarakat menjadi lebih paham mengenai infertilitas dan merubah paradigma negatif masyarakat mengenai kondisi ini. Perawat sebagai konselor juga patut untuk diutamakan karena tidak jarang pasangan yang menunda-nunda untuk berobat dengan berbagai alasan.

3. Bagi Penelitian Selanjutnya

a. Diharapkan penelitian selanjutnya agar lebih paham dan mendalami aspek terkait infertilitas, diantaranya adalah perasaan dan mekanisme koping pasangan.

b. Diharapkan penelitian selanjutnya menggunakan partisipan yang lebih bervariasi, artinya menyertakan suami sebagai subjek penelitian untuk mendukung hasil data. Lebih banyak partisipan sehingga didapatkan data yang lengkap dan terperinci.

4. Bagi Pemerintah

Pemerintah diharapkan dapat memberikan kebijakan dan ikut andil dalam masalah ini, seperti menjamin keseluruhan atau sebagian biaya pengobatan maupun pemeriksaan.

\section{DAFTAR PUSTAKA}

Aditya, Coky. 2015. Berbagai Terapi Jitu Atasi Emosi Sehari-Hari. Yogyakarta: Flashbooks

Afi, Darti Nur. 2006. Stress Dan Coping Ibu Yang Belum Mempunyai Keturunan. Medan: Universitas Sumatra Utara

Ahmadi, Abu. 2009. Ilmu Sosial Dasar. Jakarta: Rineka Cipta

Djuwantono, Tono. Dkk. (2008). Hanya 7 Hari Memahami Infertilitas. Bandung : PT. Refika Aditama

Donkor, Ernestina S \& Sandal, Jane. 2009. Coping Strategies Of Woman Seeking Infertility Treatment In Southern 
Ghana. African Journal Of Reproductive Vol 13 No.4 Desember 2006

Ma'rifah, Atun, Raudatul. 2010. Respon Dan Koping Perempuan Yang Mengalami Infertilitas Yang Dipengaruhi Faktor Sosial Budaya Banyumas Di Kecamatan Kembaran Kabupaten Banyumas, Jawa Tengah; Studi Grounded Theory. Jakarta: FIK UI

Moleong, Lexy J. 2011. Metodologi Penelitian Kualitatif Edisi Revisi. Bandung: PT Remaja Rosda Karya

Mousavi, Seyyedh Samira, Dkk. 2015. The Relationship Between Social Support And Mental Health In Infertility Women: The Mediating Role Of Problem-Focused Coping. Journal of Applied Of Medical Science, 3,244248. Iran: Shahid Chamran University

Nurfita, Eva. 2007. Mekanisme Koping Pasangan Infertilitas Di Kecamatan Singkil Kabupaten Aceh Singkil. Skripsi Medan: Universitas Sumatera Utara

Papalia, Dkk. (2009). Perkembangan Manusia. Jakarta: Salemba Humanika

Pedro, Athena. 2015. Coping With Infertility: An Explorative Study of South African Women's experiences. Journal Of Obstetric And Gynecology, $5,49-59$

Ramamurthi Et.Al (2016). Psychological Impact And Coping Strategies Among Women With Infertility,3,2016:114118. India

Sitepu, Imelda Mutiara. 2014. Mekanisme Koping Pada Perempuan Suku Karo Yang Mengalami Infertilitas Di Kabanjahe Kec. Kabanjahe Kab. Karo. Tesis. Medan: Universitas Sumatra Utara
Soimah, Nurul \& Hidayat, Asri. 2011. Psikologi Perempan Dengan Masalah Infertilitas Sekunder Studi Fenomenologi Pada Psien Di Poliklinik Kebidanan Rumah Saki Ibu Anak Aisyh Muntilan Kabupaten Magelang Tahun 2011. Naskah Publikasi. Yogyakarta: Sekolah Tinggi Ilmu Kesehatan 'Aisyiyah

Sugiarti, Lintang. 2008. Gambaran Penerimaan Diri Wanita Yang Involuntary Childless. Skripsi. Jakarta: Universitas Indonesia

Sugiyono. 2014. Memahami Penelitian Kualitatif. Bandung: Alfabeta

Sulistyaningsih. 2011. Metodologi Penelitian Kebidanan KuantitatifKualitatif. Edisi I. Yogyakarta: Penerbit Graha Ilmu

Trisnawati, Yuli. 2015. Analisis Kesehatan Reproduksi Wanita Ditinjau Dari Riwayat Kesehatan Reproduksi Terhadap Infertilitas Di Rs Margono Soekardjo Tahun 2015. Jurnal Kebidanan Vol. Vii, No. 02, Desember 2015. Purwokerto

Ulfah, Siti Mariyah \& Mulyana, Olievia Prabandini. 2014. Gambaran Subjective Well Being Pada Wanita Involuntary Childless. Surabaya: Universitas Negeri Surabaya. Jurnal Psikologi Vol 02 Nomor 3 Tahun 2014)

Ulina, Bebi Wanda Sri. 2016. Gambaran Mekanisme Koping Pada Pasien Luka Kaki Diabetes Di Asri Wound Care Centre. Skripsi. Medan: Universitas Sumatra Utara

Vitahealth. 2007. Infertil. Gramedia Pustaka Utama. Jakarta 